\title{
O Papel de um Comitê de Bioética na Reafirmação da Prática Humanizada
}

\author{
Muller, Walter; Ferraz, Dayse M. de Melo Coelho; Barroco, Maria de Fatima \\ Candido; Pinto, Ester Oliveira \\ Hospital Geral de Sao Mateus — w-muller@uol.com.br
}

Introdução em 2008, foi instituído neste hospital publico, da rede SUS, na zona leste de São Paulo, um Comitê de Bioética composto por equipe multidisciplinar de profissionais da instituição e representantes da comunidade Objetivo uma das funções do comitê é atender a demanda das equipes multiprofissionais, frente a conflitos éticos e morais. Problema: a abordagem à questão de gênero e diversidade sexual dentro do âmbito hospitalar motivava conflitos e divergências afrontando diretamente a humanização da assistência prestada ao paciente. Metodologia o problema foi apresentado ao Comitê de Bioética, que promoveu várias discussões e reflexões sobre o tema e os princípios éticos da autonomia, dignidade e respeito a diversidade. Foram realizados 02 (dois) seminários, de caráter sensibilizador e formativo para a equipe multiprofissional da instituição Resultados Houve mudança na postura da instituição em relação ao tema da diversidade sexual e sua abordagem. Foram resgatadas as normatizações legais existentes e uma abertura para busca de ajuda e apoio na prática assistencial. Foi confeccionada uma carta de recomendação dirigido a diretoria do hospital para implantação de um protocolo de atendimento para a diversidade sexual e de gênero, com base na legislação a respeito e nos referenciais bioéticos Se constituiu uma equipe multiprofissional de referência para os casos de duvidas ou conflitos e um fluxo de encaminhamento para rede de atenção e proteção existente. Conclusões: o acolhimento desta demanda pelo Comitê de Bioética resultou no fortalecimento do papel do mesmo dentro da instituição, reafirmando seu status de referencia para as questões e dilemas surgidos nas ações de humanização e ampliando o reconhecimento deste espaço para reflexão e analise dos conflitos que envolvem valores éticos e morais na pratica assistencial. Referencias: -Decreto 55.588/10 - assegura às pessoas transexuais e travestis o direito à escolha do nome social pelo qual querem ser chamadas nos órgãos públicos do Estado de São Paulo -Lei 10.948/01 - importante lei para o segmento de Lésbicas, Gays, Bissexuais, Travestis e Transexuais (LGBT), já que pune a discriminação homofóbica em razão da orientação sexual ou identidade de gênero. -Zoboli, Elma Lourdes Campos Pavone; Barchifontaine, Christian de Paul de. Bioética, Vulnerabilidade e Saúde - Editora: Idéias \& Letras

Muller, Walter; Ferraz, Dayse M. de Melo Coelho; Barroco, Maria de Fatima Candido; Pinto, Ester Oliveira. O Papel de um Comitê de Bioética na Reafirmação da Prática Humanizada. In: Anais do Congresso Internacional de Humanidades \& Humanização em Saúde [= Blucher Medical Proceedings, num.2, vol.1]. São Paulo: Editora Blucher, 2014. ISSN 2357-7282

DOI 10.5151/medpro-cihhs-10545 